\title{
Modeling the relative importance of ecological factors in exotic invasion: The origin of competitors matters, but disturbance in the non-native range tips the balance
}

\author{
Sa Xiao ${ }^{\mathrm{a}}$, Ragan M. Callaway ${ }^{\mathrm{c}}$, Ryan Graebner ${ }^{\mathrm{c}}$, Jose L. Hierro ${ }^{\mathrm{d}}$, Daniel Montesinos ${ }^{\mathrm{b}, \mathrm{c}, \mathrm{e}, *}$ \\ a State Key Laboratory of Grassland and Agro-Ecosystems, School of Life Science, Lanzhou University, Lanzhou 730000, People's Republic of China \\ b Centre for Functional Ecology, Department of Life Sciences, University of Coimbra, Calçada Martim de Freitas, 3000-456 Coimbra, Portugal \\ ${ }^{c}$ Division of Biological Sciences and the Institute on Ecosystems, The University of Montana, Missoula, MT 59812, United States \\ d CONICET-Universidad Nacional de La Pampa (UNLPam), 6300 Santa Rosa, Argentina \\ e CIDE (CSIC-UV-GV), Carretera Montcada-Nàquera, Km 4.5, 46113 València, Spain
}

\section{A R T I C L E I N F O}

\section{Article history:}

Received 10 December 2015

Received in revised form 6 May 2016

Accepted 8 May 2016

\section{Keywords:}

Biogeography

Competition

Disturbance

Individual-based model

Modeling

Centaurea solstitialis

\begin{abstract}
A B S T R A C T
Successful exotic plant invasions are likely to be caused by multiple, non-mutually exclusive mechanisms, and it is exceptionally difficult to weight the relative importance of these mechanisms identified in different experiments. To this end we used individual-based models to explore how integrating empirical results from experiments might help to elucidate the relative importance of seed origin, biogeographic differences in competitive outcomes, and disturbance in exotic plant invasion. We integrated results from (1) competition experiments between Centaurea solstitialis derived from populations in the nonnative range (California), the native range (Spain), and co-occurring native species from both ranges, (2) seed production by Centaurea plants from the different ranges grown in a common-garden environment, and (3) responses to disturbance experiments with plants from different native and non-native ranges. Californian C. solstitialis reached slightly higher abundances than its Spanish counterparts in every scenario, mainly due to higher seed production of Californians than their Spanish conspecifics, indicating the potential importance of evolutionary changes in the non-native range. In the absence of disturbance, grass species native to Europe showed stronger competitive effects on $C$. solstitialis than grass species native to North America, suggesting that release from competition in the native range may have some explanatory power for successful $C$. solstitialis invasion. However, the intensity of competition depended on the disturbance regime used in models. When intense disturbance was incorporated into the model, $\mathrm{C}$. solstitialis was favored, with plants from Californian seed sources reaching higher densities than plants from Spanish seed sources. Our results are consistent with the idea that disproportional positive responses to disturbance in California, relative to those in the invader's native range of Spain, may be an important factor in the dominance of $C$. solstitialis in its non-native ranges. It is not clear why disturbance would have more beneficial effects on the invader in its non-native range, but the powerful effects of disturbance appear to interact in subtle ways with biogeographic differences in evolutionary trends, competitive intensities, life histories, and reproductive rates.
\end{abstract}

(c) 2016 Elsevier B.V. All rights reserved.

\section{Introduction}

Successful exotic plant invasions appear to be affected by a number of biogeographically explicit ecological processes,

\footnotetext{
* Corresponding author at: Centre for Functional Ecology, Department of Life Sciences, University of Coimbra, Calçada Martim de Freitas, 3000-456 Coimbra, Portugal. Tel.: +351-239 240700

E-mail addresses: xiaos@lzu.edu.cn (S.Xiao),ray.callaway@mso.umt.edu (R.M. Callaway), jhierro@conicet.gov.ar (J.L. Hierro), danimontesinos@gmail.com (D. Montesinos).
}

including appropriate propagule pressure for establishment, spread, and occupation (Von Holle and Simberloff, 2005), competition with local residents (García-Serrana et al., 2007; Maron and Marler, 2008; Callaway et al., 2011), consumer pressure (Kulmatiski et al., 2008; Pearson et al., 2011; Schaffner et al., 2011), and responses to disturbance (Leishman and Thomson, 2005; Hierro et al., 2006). These ecological phenomena are likely to interact in complex ways, and this creates opportunities for ecologists to explore the combined or synergistic effects of complex mechanisms on invader abundance and impacts on native species (Lenz and Facelli, 2005; Besaw et al., 2011). However, ascertaining the 
relative importance of different ecological mechanisms is difficult for several reasons. First, it is hard to know whether mechanisms that are important at small scales, competition for example, are also important at the scale of invaded landscapes. Second, manipulating some combinations of mechanisms in biogeographically explicit field experiments, such as herbivory and competition, is problematic because of the risk of introducing additional non-native species or genotypes. Third, field experiments yield perspectives from the particular suite of conditions in which they are conducted, and it is difficult to extrapolate from one suite of conditions to others in order to derive more general hypotheses.

One approach to building and strengthening hypotheses for the relative importance and potential synergy of multiple interacting mechanisms in ecology is the use of empirical and individual-based modeling. These models can integrate experimental results that vary in intensity in order to assess potential conditionality in their relative importance and the generality of a mechanisms across a range of conditions. Individual-based models cannot replace multifactorial field experiments, but they can provide a tool to develop hypotheses for causal links between individual-level interactions and ecological patterns at the population or community level (Grimm and Railsback, 2005). They are also suitable for investigating the characteristics and dynamics of complex systems, which are typical in ecological research, and in particular in the studies of communities (Chen et al., 2009; Xiao et al., 2009, 2010; Michalet et al., 2011).

A number of mechanisms appear to contribute to the invasiveness of Centaurea solstitialis L. (yellow starthistle) in California, including disturbance (Hierro et al., 2006), evolution of new trait responses in non-native ranges (Hierro et al., 2009; Dlugosch et al., 2015), weak density-dependent competitive resistance by native North American species in invaded grasslands (Munshaw and Lortie, 2010), escape from soil pathogens (Hierro et al., 2006; Andonian et al., 2011), competitive interactions (Graebner et al., 2012), and compensatory responses by individuals and populations to herbivory (Callaway et al., 2006; Garren and Strauss, 2009). However, for most if not all invasions, the relative importance of these and other mechanisms is unknown. Here, we use individual-based models to integrate several empirically derived datasets from different studies to develop hypotheses for the relative importance of disturbance, region-specific competitive intensities, and regionbased differences in seed production in C. solstitialis invasion. For each mechanism, we incorporated biogeographic differences from experiments or measurements made for populations from the native and non-native ranges, allowing us to compare mechanisms in a biogeographical context after Hierro et al. (2006).

\section{Methods}

\subsection{Overview}

Centaurea solstitialis is a summer annual herb native of Eurasia and a highly aggressive invader in California, parts of South America, and Australia (Gerlach and Rice, 2003; Hierro et al., 2009). For our individual-based models, we integrated results from (1) an experiment comparing the intensity of competitive interactions (Relative Interaction Intensities; RII; Armas et al., 2004) between C. solstitialis from populations with North American and Spanish native grasses, to the competitive intensity of the same competitive interactions for $C$. solstitialis from Spain, (2) a common greenhouse experiment in which reproduction was compared for $C$. solstitialis plants from Spanish and Californian populations, and (3) results reported by Hierro et al. (2006) for the responses of $C$. solstitialis to experimental disturbance in California and another part of its native range, southwestern Turkey. We did not conduct a fully factorial test of each of these processes, but applied biogeographic differences in reproductive rates and responses to disturbance to two different competitive scenarios; one created with $C$. solstitialis from California and grass species native to California, and one created with $C$. solstitialis from Spain and grasses native to Spain.

\subsection{Assessment of competitive interactions}

Centaurea solstitialis seeds were collected from ten individuals of each of eight populations across California and eight populations across Spain. Grasses native to Spain (Aegilops geniculata, Avena barbata, and Brachypodium distachyon) or California (Bromus carinatus, Elymus glaucus, Hordeum brachyantherum, and Poa secunda) were either collected from the wild in California or purchased (S\&S Seeds, Carpinteria, CA, USA). Grasses represented species from a variety of common genera that overlap with the distribution of Centaurea solstitialis in its European and North American ranges. All species belong to Mediterranean habitats were germination occurs during the rainy season (i.e. winter). Spanish grasses have been introduced into California (plants.usda.gov), where they are widespread and commonly co-occur with C. solstitialis. Importantly, introduced European grass species were annuals, while Californian native grasses were perennial. Since our model incorporates a range of disturbance levels, the differences in life-history (annual invasive vs. perennial native grasses) could have an effect on our models, although such effect should be minimized at high disturbance rates, since on highly disturbed sites both annuals and perennials would be expected to perform as annuals.

For the competition contests we used five maternal lines from each of the eight Centaurea populations from each of the two regions (Spain or California). For each of these maternal lines, we sown in pots nine replicate $C$. solstitialis seeds, seven seeds in one-on-one competition with seeds of each of the seven grass species, and two controls. We also planted five replicates per population for one-on-one competition with another individual from the same Centaurea population, and five replicates for controls. Finally, we planted twenty replicates of each of the following: controls for each of the seven grass species, grass species in oneon-one competition with another individual of the same species, and one-on-one competition for each pair of grass species from the same region (i.e. within Spain or within California). Seeds were sown and germinated directly in pots and grown for 90 days in a greenhouse where temperatures were kept between $15^{\circ} \mathrm{C}$ at night and $30^{\circ} \mathrm{C}$ in the day, and natural light was supplemented with metal halide bulbs. Photosynthetic Active Radiation during the day peaked at $\approx 1500 \mu \mathrm{mol} \mathrm{m}{ }^{-2} \mathrm{~s}^{-1}$ on cloudless days. We harvested plants 90 days after planting while they were in vegetative (non-reproductive) state. Each plant was dried for $72 \mathrm{~h}$ at $90^{\circ} \mathrm{C}$ and weighed. Total mean masses for all controls and competition treatments are reported in Table 1.

From these pairwise competition contests we constructed an orthogonal matrix of RIIs depicting the intensity of each pair-wise interspecific interaction between $C$. solstitialis from either Spain or California, and three grass species native to Spain and four grass species native to California, all intraspecific RIIs, and RIIs among all Spanish grass species (with the exception of Aegilops) and among all Californian grass species (Appendix Tables A1-A4). This index has defined limits between -1 (competition) and +1 (facilitation), it is symmetrical around zero, and it is calculated as follows:

$\mathrm{RII}=\frac{\left(B_{w}-B_{0}\right)}{\left(B_{w}+B_{0}\right)}$,

in which $B_{0}$ represents the mass of control individuals and $B_{w}$ the mass of individuals in competition. 
Table 1

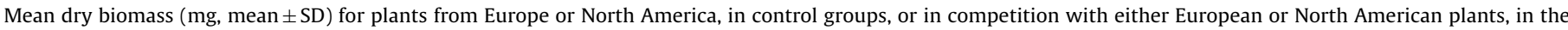
absence of disturbance.

\begin{tabular}{|c|c|c|c|c|}
\hline & European C. solstitialis & North American C. solstitialis & European grasses & North American grasses \\
\hline Control & $137 \pm 48$ & $186 \pm 36$ & $305 \pm 35$ & $301 \pm 34$ \\
\hline Competition with Europe & $39 \pm 25$ & $59 \pm 34$ & $337 \pm 129$ & $206 \pm 95$ \\
\hline Competition with North America & $62 \pm 41$ & $92 \pm 53$ & $290 \pm 99$ & $199 \pm 103$ \\
\hline
\end{tabular}

\subsection{Assessment of reproductive rates}

We measured the reproductive rates of $C$. solstitialis from California and Spain in another greenhouse experiment in which pollinators were excluded (see Montesinos et al., 2012 for detailed methodology). For each of the 10 mother plants from each of the 16 populations, we sowed one seed in a $2 \mathrm{~L}$ pot and grew them under common greenhouse conditions. We grew $C$. solstitialis until the plants flowered and manually pollinated all capitula (from now on named flower-heads) within populations to obtain seed-set. Centaurea solstitialis plants from Spain and California produced a similar number of flowers (mean $\pm \mathrm{SD}=27 \pm 3$ flowers per individual; D. Montesinos, unpublished data); consequently, reproductive rates for an individual were calculated as the mean number of seeds produced per capitulum (8.24 for Spain, and 9.33 for California) multiplied by the mean germination rate (37\% for Spain, and $60 \%$ for California), which equaled 5.6 germinated seeds per flowerhead for Californian populations and 3.0 germinated seeds per flower-head for Spanish populations. Since we did not have measurements of the reproductive rates for grass species, we assigned a single reproductive rate to all grasses in the models that equal the mean value of Californian and Spanish C. solstitialis reproductive rates: 4.3 , which did not favor model outcomes in either biogeographic scenario. Additionally, we conducted a sensitivity analysis by including native reproductive values from 2.16 to 8.64, to assess the robustness of our models. We assumed annual reproduction for all species.

\subsection{Assessment of the effect of disturbance}

Hierro et al. (2006) investigated the effects of disturbance on the success of $C$. solstitialis in California and in its native Turkey by simulating different field disturbances and adding locally collected $C$. solstitialis seeds. They found that disturbance increased $C$. solstitialis density and relative performance far more in non-native ranges than in the native range. We used results from Hierro et al. (2006) to model biogeographic responses to disturbance in the context of the other factors studied here. We used post-disturbance $C$. solstitialis densities from native and non-native ranges to calculate a constant " $c$ ". We divided post-disturbance density in the native range by post-disturbance density on the non-native range. Therefore " $c$ " values lower than one would indicate that native C. solstitialis populations are more negatively affected by disturbance than non-native populations, and values higher than one would indicate that nonnative populations were more negatively affected by disturbance than native populations. Therefore, the obtained value of $c=0.403$ indicates a more negative impact of disturbance on $C$. solstitialis populations in the native range than populations in the non-native range.

\subsection{Model design}

We used the RII matrix described above to build an individualbased spatially explicit dual-lattice model (Travis et al., 2005, 2006; Michalet et al., 2011) with C. solstitialis and all native species occupying one two-dimensional lattice $(100 \times 100$ cells $)$ for California and Spain, respectively. Each individual of each $C$. solstitialis and each native species occupied one cell in the lattice. When reproduction occurred (annually), individuals produced propagules that were identical to their parents. The total number of these propagules equalled the reproductive rate $r_{C}$ of the $C$. solstitialis plant and the reproductive rate $r_{N}$ of the native species. $r_{C}$ was 5.598 in California and 3.045 in Spain, and $r_{N}$ was the same for all native species populations, which equaled 4.321. All propagules of $C$. solstitialis and native species were dispersed sequentially to one of the patches that were randomly selected within the lattice. The propagules were only allowed to establish in empty cells and the propagule arriving first occupied the cell. We used a "wraparound" (torus) approach to avoid edge effects (Yamamura et al., 2004).

We assumed that both intra- and inter-specific competition decrease the survival rate of the species, and that this negative effect increases linearly with the increase of the RII value. Individuals competed only with other individuals within a neighborhood, and the neighborhood was defined as the Moore neighborhood in our model, including eight immediate neighbors of a given cell: north, northeast, east, southeast, south, southwest, west and northwest (Ifti et al., 2004).

Therefore, the survival rate of species $i$ was:

$S_{i}=S_{\max }-\sum_{j=1}^{n}\left(\frac{\mathrm{RII}_{j} \text { on } \mathrm{i}}{8}\right)$

where $S_{\max }$ was the maximum survival rate of the species without competition, and we assumed that it was the same for all species, with a value equal to 0.8 . However, we conducted a sensitivity analysis with $S_{\max }$ values equalling to $0.4,0.6$ and 1.0 , to confirm the robustness of our models. RII $_{j}$ on $i$ indicates the competitive RII values of neighboring species $j$ on species $i$. $n$ is the total number of neighboring plants of one individual of species $i$.

To account for the impact of disturbance, we defined $d$ as the intensity of disturbance in both the native and non-native ranges, ranging from 0 to 1 . In our models, $d$ was set to 0 (no disturbance), 0.1 (low disturbance), 0.4 (moderate disturbance) and 0.7 (high disturbance). We assumed that the impact of disturbance also decreased the survival rate of species and that this impact increased linearly with the increase of the $d$ value. Therefore, the survival rate of species $i$ experiencing disturbance was:

$S_{i}=S_{\max }(1-c * d)-\sum_{j=1}^{n}\left(\frac{\mathrm{RII}_{j} \text { on } \mathrm{i}}{8}\right)$

As described above, $c$ equals 0.403 for Californian $C$. solstitialis, and 1 for Spanish C. solstitialis, and 1 for all native species both from North America and Europe. We used asynchronous updating in the model that worked in the following way. First a single individual of species was selected at random. Second, we determined whether the individual survived at a certain survival rate $S_{i}$. If the individual survived it reproduced and dispersed propagules. Each time step was made up of $N$ of such updates, where $N$ referred to the number of all individuals within the community. Since the initial population sizes of invaders are likely to be relatively small at the beginning of invasions, all simulations were initiated with only 100 individuals of Californian C. solstitialis. Initial conditions started with saturated communities of native species with each having the same number 


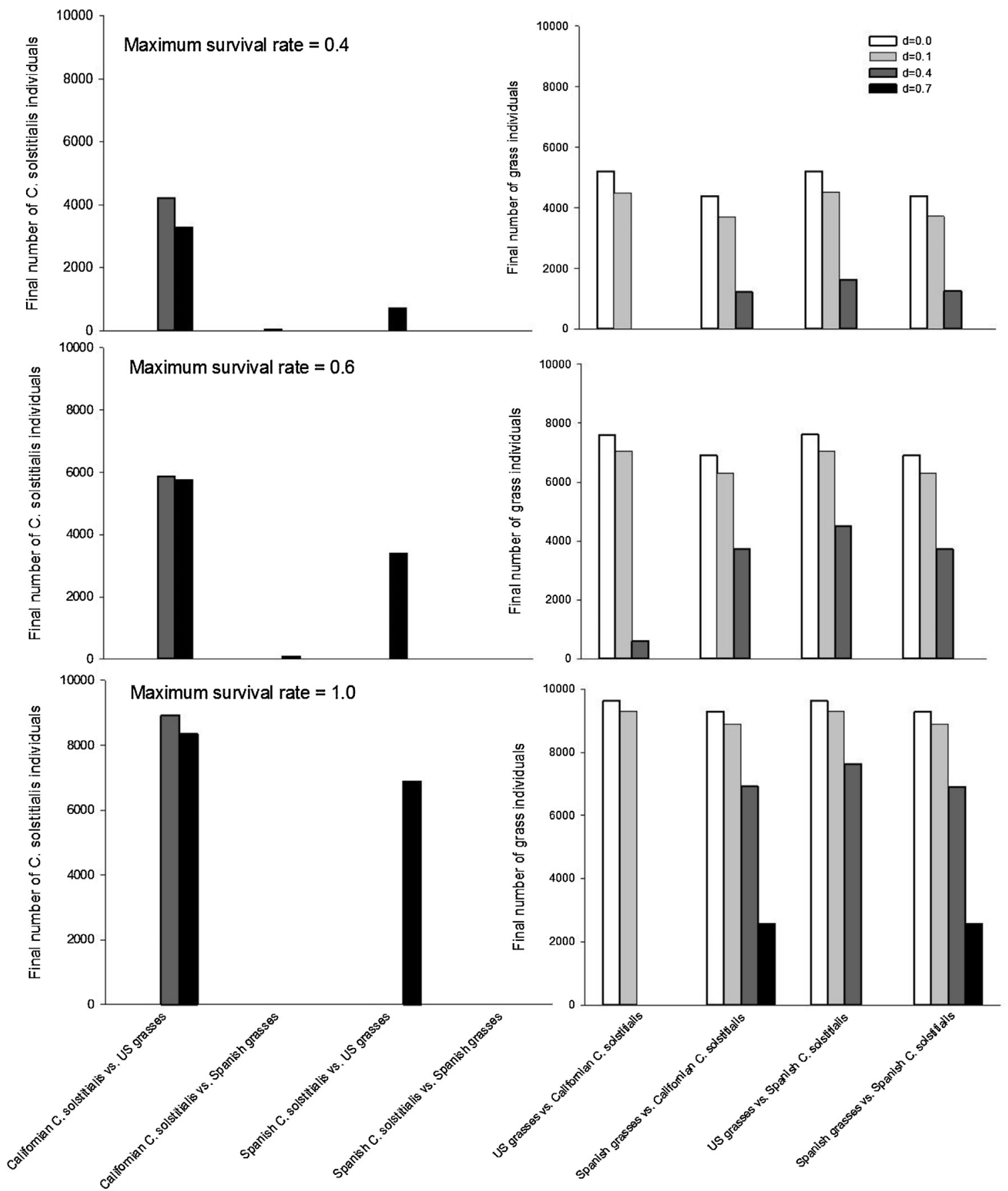

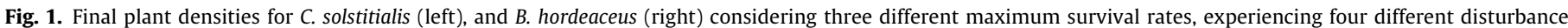
levels (d).

of individuals. All individuals of species were randomly dispersed across the lattice.

All simulations were run for 10,000 time steps in order to allow the system to reach a steady state. However, note that all simulations reached stable proportional of species before 100 generations. Centaurea solstitialis was introduced to California roughly 200 years ago, thus even assuming a time lag from the first introduction until high densities were reached our simulations generally correspond with the timeframe of $C$. solstitialis invasion. All measurements were determined as the mean values of 100 independent replicate runs for each time step. Simulations were performed in NetLogo (Wilensky, 1999, http://ccl.northwestern.edu/netlogo/), a powerful multi-agent modeling language particularly well suited for modeling complex systems that develop over time. Both the ODD protocol (Grimm et al., 2010) and the NetLogo code for the model used can be found as Supplementary Information 1 and 2, respectively.

\section{Results}

\subsection{Response of Centaurea solstitialis}

In the absence of disturbance, the modeled abundance of $C$. solstitialis decreased rapidly in all scenarios but one, and was 

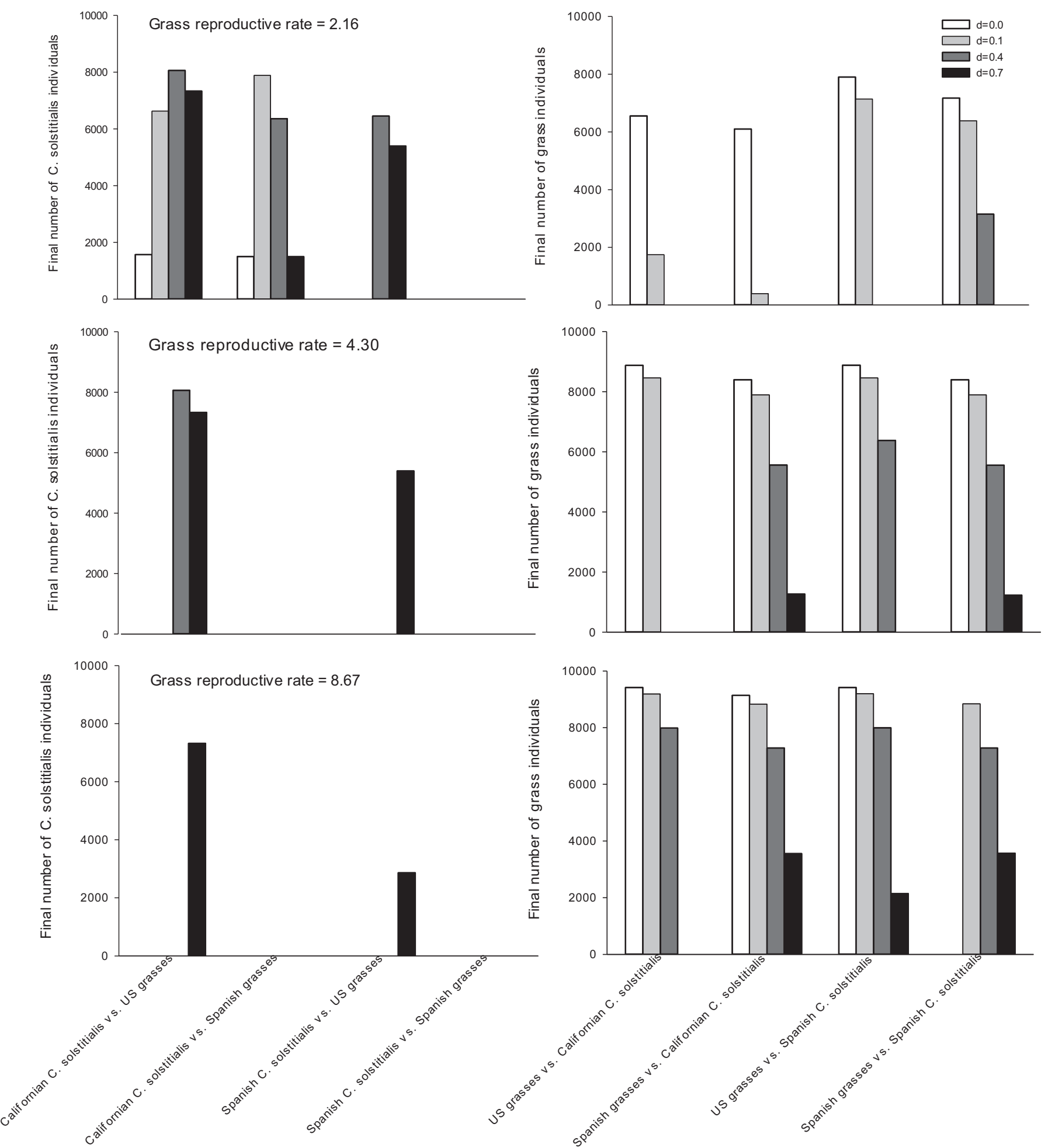

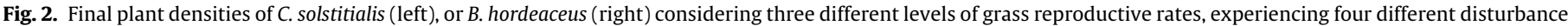
levels (d).

eliminated in less than 50 time steps (Figs. 1 and 2). In one case, utilizing a very low grass reproductive rate, a Californian $C$. solstitialis population was able to persist (Fig. 2). In all scenarios, the final abundance of $C$. solstitialis was slightly higher, and $C$. solstitialis survived for a short time longer, when competing with native North American grasses than when competing with native European grasses. Nevertheless, the final abundance of $C$. solstitialis was consistently much higher when moderate or high levels disturbance occurred across all survival and reproductive rates.

At the lowest level of disturbance, $C$. solstitialis abundances were higher than without disturbance, but decreased rapidly, and $C$. solstitialis was eliminated from the models with native European grasses in approximately 10 time steps. The models with native North American grasses required roughly 50 time steps for the 
extirpation of $C$. solstitialis. At moderate disturbance levels, $C$. solstitialis became dominant only when in competition with native North American grasses. Centaurea solstitialis from both ranges were rapidly eliminated from the model when in competition with native European grasses. Similar results occurred at high disturbance levels, with $C$. solstitialis becoming highly abundant in competition with Californian grasses but not when in competition with Spanish grasses.

The sensitivity analysis for grass reproductive rates showed that increasing grass reproductive rates decreased the final densities of C. solstitialis. However, even at the highest grass reproductive rate, C. solstitialis populations were able to establish, with higher final abundances for populations of Californian origin. Thus the sensitivity analyses showed that our modeled outcomes were robust regardless of grass reproductive rates.

\subsection{Responses of North American and European grasses}

Modeled dynamics of the abundances of grass species native to North America versus those native to Europe, with all species in each region combined, reflected those for the abundance of C. solstitialis. Without disturbance and at low disturbance levels native grasses from both regions rapidly became dominant, reflecting differences between the regions in competitive outcomes and matching the rapid decline in C. solstitialis abundance.

In moderate disturbance levels modeled outcomes were strikingly different than without disturbance. There were substantial decreases in the abundance of native grasses in both ranges, but stronger decreases for North American grasses. At the moderate disturbance level, North American grasses abundances decreased sharply and were ultimately eliminated from the model.

At the highest disturbance level, the abundance of native grasses decreased substantially for plants from both ranges, but native grass species remained in the system and reached stable levels when in competition with Spanish $C$. solstitialis. At this high disturbance rate, all native grasses were extirpated within 10 time steps when in competition with Californian C. solstitialis. Results from sensitivity analyses, with $S_{\max }$ values equalling $0.4,0.6$ and 1.0 were qualitatively the same as those reported above, again indicating that the general patterns in our models were robust. Sensitivity analyses using different reproductive rates for different grass species were qualitatively similar, although higher reproductive levels for grasses resulted in slightly lower final densities of $C$. solstitialis.

\section{Discussion}

Our models supported the fundamental importance of disturbance for invasion by Centaurea solstitialis. Differences in competitive interactions and reproductive rates may contribute to higher relative abundances of $C$. solstitialis in its non-native range than in its native range, but biogeographic differences in competitive outcomes were not manifest without disturbance. To best illustrate the interaction between disturbance and biogeographically based competition, even at moderate or high disturbance rates, $C$. solstitialis reached dominance (i.e. the most abundant species in the community) in competition with Spanish grasses only when survival rates were set to be lower than one, or when grasses' reproductive rates were set to the lowest point. However, C. solstitialis became dominant in high disturbance rates in competition with Californian native grasses regardless of biogeographic differences in reproductive rates or survival rates.
We do not have data for grass reproductive rates, but our models suggest that abundant native seed availability might be crucial for controlling $C$. solstitialis invasion. Furthermore, the modeled effect of disturbance on survival rates was important, since only in the models in which survival responses to disturbance were moderate or low were systems dominated by $C$. solstitialis, regardless of the origin of the grass species.

Our models incorporated relative biogeographical differences in greenhouse-based competitive outcomes and reproductive rates with relative biogeographical differences in the abundance of $C$. solstitialis and native species in field experiments with disturbance, the outcome of which was also affected by competition and reproductive rates. Therefore, we have not tested each mechanism in a factorial manner, and thus our models only suggest potential directions in which to focus more intensely in order to better understand C. solstitialis invasion. These models suggest that biogeographical differences in response to disturbance might be crucial. Disturbance is associated with nearly $70 \%$ of all plant invasions (Lozon and MacIsaac, 1997), and it commonly increases the abundance of exotic plants (Gray, 1879; Elton, 1958; D’Antonio et al., 1999). Changes in resource availability (Davis et al., 2000) and disturbance (MacDougall and Turkington, 2005) have been considered more determinant of invasive success than particular species traits (Bennett et al., 2012). Experimental data consistently shows a high benefit of disturbance to $C$. solstitialis performance (Hierro et al., 2013; Gerlach and Rice, 2003). However, we know little about how disturbance affects exotics in their native ranges. For disturbance to explain biogeographic differences in the abundance of exotic invaders we must know whether disturbance triggers the same extraordinary response in the abundance of some invaders where they are natives as observed where they are exotics (Hierro et al., 2005). In our case, the competitive advantage $C$. solstitialis has against Californian grasses may be a key link to understanding why disturbance has a stronger effect in California than in the native range of the invader.

The vast majority of California grasslands have been invaded by European grasses, which are common competitors of $C$. solstitialis in California. Our results indicate that $C$. solstitialis dominates grass communities at high disturbance rates regardless of the origin of the grass community, but European grasses survive with C. solstitialis although at much lower densities. This suggest that ruderalization of native plant communities in California greatly facilitates invasive processes by ruderal species like $C$. solstitialis. One other potential biogeographical mechanism that might explain the stronger positive effects of disturbance in the nonnative ranges of $C$. solstitialis, is soil biota. For example, Hierro et al. (2006) found that soil from the native range suppressed the growth of $C$. solstitialis, whereas soil biota from two non-native ranges did not. However, other biogeographical comparisons of soil biota are not as clear. Andonian et al. (2012) found that soil biota from both native and non-native ranges of $C$. solstitialis had negative effects on plants, but these negative effects were significantly weaker in soils from non-native ranges in Chile and California than in those from the non-native range in Argentina and the native range in Eurasia, patterns that did not correspond completely with the strength of invasion in non-native ranges. In another study, Andonian et al. (2011) found that C. solstitialis generated strong negative feedbacks in regions where it is the most invasive but neutral plant-soil feedbacks where it is non-invasive.

A leading hypothesis for invasive success is escape from natural enemies, and therefore a major gap in our study is that we did not incorporate effects of herbivores. However, $C$. solstitialis may actually experience greater attack by biological control agents in its introduced range in California than it does in its native range. In California, biological control weevils can be found in 
over $50 \%$ of $C$. solstitialis inflorescences and on over $90 \%$ of plants (Gutierrez et al., 2005; Swope and Parker, 2010a,b), but in native regions in Eurasia no more than $18 \%$ of plants in a population have been found to be infested (Uygur et al., 2004). And Wallace et al. (2008) found that livestock herbivory early in the growth of C. solstitialis in its non-native range stimulated overcompensation in reproduction. Similarly, Garren and Strauss (2009) found that two biocontrol agents strongly reduced seed production but that several compensatory processes prevented effective population control. Self-thinning, apparently caused by intraspecific competition, reduced the numbers of seedlings to the point where the effects of biocontrol agents were not detected. Swope and Parker (2010a,b) found a similar pattern for C. solstitialis, in which initial high plant density resulted in lower final C. solstitialis density, but having no overall effect on fitness due to compensatory reproductive responses of surviving adults. Other studies have shown that biocontrol agents can decrease seed production by $40-100 \%$ per head (Pitcairn and DiTomaso, 2000), and yet others suggest that this effect may not significantly reduce yellow starthistle populations (Turner and Fornasari, 1992; Sun and Ritland, 1998; DiTomaso and Gerlach, 2000). The incorporation of any biogeographic differences in herbivore effects would have improved our models, but a number of studies suggest that specialist and generalist herbivores do not have unusually strong effects in the non-native range of $C$. solstitialis.

A second weakness of our model is that we did not incorporate variation in the reproductive rates of the Californian and European grasses. Instead, we simply set these reproductive rates at an arbitrary but identical background against which the consequences of experimentally measured variation in the reproductive rates of $C$. solstitialis could be estimated. Thus, it is important to note that the outcome of biological interest in this context is the effect of the relative difference in measured reproductive rate of plants from Californian and Spanish populations of C. solstitialis. Regardless, our results are likely to be representative only for similar annual herbs presenting strict sexual reproduction in disturbed ruderal habitats.

We do not know the mechanism for why $C$. solstitialis had stronger competitive effects on North American native grasses than on European grasses, but common explanations for such differences, such as novel allelopathic effects (Callaway and Ridenour, 2004; Inderjit et al., 2011; Svensson et al., 2013) are unlikely to apply. Qin et al. (2007) found that experiments with activated carbon, crude root exudates, and chloroform-extracted root exudates from $C$. solstitialis did not demonstrate evidence for allelopathic inhibition of native North American species. Furthermore, field experiments testing the effects of competition in two non-native ranges, California and Argentina, competition from annual grasses and perennial grasses reduced $C$. solstitialis performance similarly in both ranges (Hierro et al., 2011). In contrast, Munshaw and Lortie (2010) added C. solstitialis seed into existing vegetation and found no evidence for regulation of the invader via intra or interspecific competition in the non-native range.

Our measurements of greater reproductive rates for Californian populations than Spanish populations support the possibility that evolution has occurred in the non-native range. Recent studies point to changes in the reproductive system, which is establishing reproductive barriers between populations in the native and non-native ranges of the species (Montesinos et al., 2012). Other studies have found differences between $C$. solstitialis derived from its native and non-native ranges in germination, relative growth rates, competitive resistance, seed and seedling mass, resistance to disturbance, and resource use (Hierro et al., 2006, 2009, 2013; Graebner et al., 2012; Dlugosch et al., 2015). These changes might be partially responsible for the results observed in our simulations.
Regardless, our models primarily point to biogeographical differences in the effects of disturbance, with other factors appearing to be secondary. Our simulations indicate that an important aspect of biotic resistance to $C$. solstitialis in the non-native ranges is the competitive effects of native grass species, which is consistent with empirical studies (Gerlach and Rice, 2003; Hierro et al., 2011, 2013). Disturbance has negative effects on native grass species in the Californian scenarios, which of course reduces their ability to competitively resist $C$. solstitialis. Disturbance also had a direct negative effect on C. solstitialis, but the impact of disturbance was lower for $C$. solstitialis than for grass species, particularly for grass species native to North America. Our results also suggest that the ruderalization of native Californial grasslands could be key to facilitating invasive processes by exotic species pre-adapted to high disturbance regimes.

\section{Conclusions}

The most important contribution of our work is to provide a suggestion for how ecologists might link small-scale mechanistic results to ecological patterns at the population or community level (Grimm and Railsback, 2005), and through this linkage to estimate the relative importance of different smaller scale results. In our case, our models point most strongly to the need to explore biogeographic differences in disturbance as a key driver for invasion by $C$. solstitialis. But our results also indicate that escape from stronger competitive environments and evolution toward greater reproductive capacity in non-native ranges may also contribute to larger scale patterns of the invader's distribution and abundance.

\section{Acknowledgements}

RMC thanks the NSF EPSCoR Track-1 EPS-1101342 (INSTEP 3) for support. DM was funded by the Spanish Micinn (2008-0662), by the Portuguese FCT (PCT/BIA-PLA/3389/2012 and IF-00066-2013), and by the European Commission (FP7-PEOPLE-MC-CIG-321909); FCT is partially funded by the EU via QREN, COMPETE and FEDER. SX thanks the State Key Program of the National Natural Science of China (31230014, 41430749), the Program for New Century Excellent Talents in University (NCET-13-0265), the Central University Special Fund (lzujbky-2014-k09, lzujbky-2014-200), the National Key Technology R\&D Program (No. 2014BAC05B02), and the National Natural Science Foundation of China (31470492).

\section{Appendix A.}

See Tables A1-A4.

Table A1

RII values for competition between Californian C. solstitialis and North American native species. Each RII value represents the competitive effects of the species from each column on the species in each row.

\begin{tabular}{llllrr}
\multicolumn{6}{l}{ Species causing the competitive response } \\
\hline Species & Centaurea & Poa & Bromus & Elymus & Hordeum \\
\hline Centaurea & -0.238 & -0.152 & -0.226 & -0.194 & 0.085 \\
Poa & -0.107 & -0.244 & 0.028 & -0.145 & -0.071 \\
Bromus & -0.387 & -0.492 & -0.142 & -0.321 & -0.348 \\
Elymus & -0.378 & -0.421 & -0.248 & -0.301 & -0.343 \\
Hordeum & -0.491 & -0.461 & -0.151 & -0.251 & -0.215 \\
\hline
\end{tabular}


Table A2

RII values for competitive effects between Spanish C. solstitialis and North American native species. Each RII value represents the competitive effects of the species from each column on the species in each row.

\begin{tabular}{llllll}
\hline \multicolumn{6}{l}{ Species causing the competitive response } \\
\hline Species & Centaurea & Poa & Bromus & Elymus & Hordeum \\
\hline Centaurea & -0.298 & -0.059 & -0.202 & -0.175 & 0.075 \\
Poa & -0.092 & -0.244 & 0.028 & -0.145 & -0.071 \\
Bromus & -0.452 & -0.492 & -0.142 & -0.321 & -0.348 \\
Elymus & -0.444 & -0.421 & -0.248 & -0.301 & -0.343 \\
Hordeum & -0.527 & -0.461 & -0.151 & -0.251 & -0.215 \\
\hline
\end{tabular}

\section{Table A3}

RII values of competitive effects among Californian C. solstitialis and European native species. Each RII value represents competitive effects of the species from each column on the species in each row. We did not conduct pair-wise competition trials between Aegilops and the other grass species or intra-specific competition trials for Aegilops. Therefore we used the mean of RII values for the inter-specific and intra-specific competitions of Avena and Brachypodium as substitutes for the corresponding RII values of Aegilops.

\begin{tabular}{lcccc}
\hline \multicolumn{5}{l}{ Species causing the competitive response } \\
\hline Species & Centaurea & Avena & Brachypodium & Aegilops \\
\hline Centaurea & -0.238 & -0.063 & -0.026 & 0.026 \\
Avena & -0.485 & -0.250 & -0.341 & -0.341 \\
Brachypodium & -0.526 & -0.293 & -0.231 & -0.293 \\
Aegilops & -0.546 & -0.293 & -0.341 & -0.240 \\
\hline
\end{tabular}

\section{Table A4}

RII values of competitive effects among Spanish C. solstitialis and European native species. Each RII value represents the competitive effect of the species from each column on the species in each row. We did not conduct pair-wise competition trials between Aegilops and the other grass species or the intra-specific competition trials for Aegilops. Therefore we used the mean of RII values for the inter-specific and intra-specific competitions of Avena and Brachypodium as substitutes for the corresponding RII values of Aegilops.

\begin{tabular}{lcccc}
\hline \multicolumn{5}{l}{ Species causing the competitive response } \\
\hline Species & Centaurea & Avena & Brachypodium & Aegilops \\
\hline Centaurea & -0.298 & 0.044 & -0.035 & 0.108 \\
Avena & -0.494 & -0.250 & -0.341 & -0.341 \\
Brachypodium & -0.556 & -0.293 & -0.231 & -0.293 \\
Aegilops & -0.609 & -0.293 & -0.341 & -0.240 \\
\hline
\end{tabular}

\section{Appendix B. Supplementary data}

Supplementary data associated with this article can be found, in the online version, at http://dx.doi.org/10.1016/j.ecolmodel.2016. 05.005 .

\section{Appendix C. Supplementary data}

Supplementary data associated with this article can be found, in the online version, at http://dx.doi.org/10.1016/j.ecolmodel.2016. 05.005 .

\section{References}

Andonian, K., Hierro, J.L., Khetsuriani, L., Becerra, P., Janoyan, G., Villarreal, D., Cavieres, L., Fox, L.R., Callaway, R.M., 2011. Range-expanding populations of a globally introduced weed experience negative plant-soil feedbacks. PLoS ONE 6, e20117.

Andonian, K., Hierro, J.L., Khetsuriani, L., Becerra, P.I., Janoyan, G., Villareal, D., Cavieres, L., Fox, L.R., Callaway, R.M., 2012. Geographic mosaics of plant-soil microbe interactions in a global plant invasion. J. Biogeogr. 39, 600-608.

Armas, C., Ordiales, R., Pugnaire, F., 2004. Measuring plant interactions: a new comparative index. Ecology 85, 2682-2686.

Bennett, J.R., Vellend, M., Lilley, P.L., Cornwell, W.K., Arcese, P., 2012. Abundance, rarity and invasion debt among exotic species in a patchy ecosystem. Biol. Invasions 15, 707-716.
Besaw, L.M., Thelen, G.C., Sutherland, S., Metlen, K., Callaway, R.M., 2011. Disturbance, resource pulses, and invasion: short-term shifts in competitive effects, not growth responses, favor exotic annuals. J. Appl. Ecol. 48, 998-1006.

Callaway, R.M., Ridenour, W.M., 2004. Novel weapons: invasive success and the evolution of increased competitive ability. Front. Ecol. Environ. 2, 436-443.

Callaway, R.M., Kim, J., Mahall, B.E., 2006. Defoliation of Centaurea solstitialis stimulates compensatory growth and intensifies negative effects on neighbors. Biol. Invasions 8, 1389-1397.

Callaway, R.M., Bedmar, E.J., Reinhart, K.O., Silvan, C.G., Klironomos, J., 2011. Effects of soil biota from different ranges on Robinia invasion: acquiring mutualists and escaping pathogens. Ecology 92, 1027-1035.

Chen, S.Y., Xu, J., Maestre, F.T., Chu, C.J., Wang, G., Xiao, S., 2009. Beyond dual-lattice models: incorporating plant strategies when modeling the interplay between facilitation and competition along environmental severity gradients. J. Theor. Biol. 258, 266-273.

D’Antonio, C.M., Dudley, T.L., Mack, M., 1999. Disturbance and biological invasions: direct effects and feedbacks. In: Walker, L. (Ed.), Ecosystems of Disturbed Ground. Elsevier, Amsterdam, pp. 143-452.

Davis, M.A., Grime, J.P., Thompson, K., 2000. Fluctuating resources in plant communities: a general theory of invasibility. J. Ecol. 88, 528-534.

DiTomaso, J.M., Gerlach, J., 2000. Centaurea solstitialis (yellow starthistle). In: Bossard, C., Randall, J.M., Hoshovsky, M. (Eds.), Invasive Plants of California's Wildlands. California Exotic Pest Plant Council. University of California Press, Berkeley.

DlugoschF K.M., Cang, F.A., Barker, B.S., Andonian, K., Swope, S.M., Rieseberg, L.H., 2015. Evolution of invasiveness through increased resource use in a vacant niche. Nat. Plants 1, 1-5.

Elton, C.S., 1958. The Ecology of Invasions by Animals and Plants. Methuen, London, UK

García-Serrana, H., Sans, F.X., Escarre, J., 2007. Interspecific competition between alien and native congeneric species. Acta Oecol. 31, 69-78.

Garren, J.M., Strauss, S.Y., 2009. Population-level compensation by an invasive thistle thwarts biological control from seed predators. Ecol. Appl. 19, 709-721.

Gerlach, J.D., Rice, K.J., 2003. Testing life history correlates of invasiveness using congeneric plant species. Ecol. Appl. 13, 167-179.

Graebner, R., Callaway, R.M., Montesinos, D., 2012. Invasive species grows faster, competes better, and shows greater evolution toward increased seed size and growth than exotic non-invasive congeners. Plant Ecol. 213, 545-553.

Gray, A., 1879. The pertinacity and predominance of weeds. Am. J. Sci. Arts 18, $161-167$.

Grimm, V., Railsback, S.F., 2005. Individual-based Modeling and Ecology. Princeton University Press, Princeton, N.J. Woodstock.

Grimm, V., Berger, U., DeAngelis, D.L., Polhill, G., Giske, J., Railsback, S.F., 2010. The ODD protocol: a review and first update. Ecol. Model. 221, 2760-2768.

Gutierrez, A.P., Pitcairn, M.J., Ellis, C.K., Carruthers, N., Ghezelbash, R., 2005 Evaluating biological control of yellow starthistle (Centaurea solstitialis) in California: a GIS based supply-demand demographic model. Biol. Control 34, $115-131$.

Hierro, J.L., Maron, J.L., Callaway, R.M., 2005. A biogeographical approach to plant invasions: the importance of studying exotics in their introduced and native range. J. Ecol. 93, 5-15.

Hierro, J.L., Villarreal, D., Eren, Ö., Graham, J., Callaway, R.M., 2006. Disturbance facilitates invasions: the effects are stronger abroad than at home. Am. Nat. $168,144-156$.

Hierro, J.L., Eren, Ö., Khetsuriani, L., Diaconu, A., Török, K., Montesinos, D., Andonian, K., Kikodze, D., Janoian, L., Villarreal, D., Estanga-Mollica, M.E. Callaway, R.M., 2009. Germination responses of an invasive species in native and non-native ranges. Oikos 118, 529-538.

Hierro, J.L., Lortie, C.J., Villarreal, D., Estanga-Mollica, M.E., Callaway, R.M., 2011. Resistance to Centaurea solstitialis invasion from annual and perennial grasses in California and Argentina. Biol. Invasions 13, 2249-2259.

Hierro, J.L., Eren, Ö., Villarreal, D., Chiuffo, M.C., 2013. Non-native conditions favor non-native populations of invasive plant: demographic consequences of seed size variation? Oikos $122,583-590$

Ifti, M., Killingback, T., Doebeli, M., 2004. Effects of neighbourhood size and connectivity on the spatial Continuous Prisoner's Dilemma. J. Theor. Biol. 231, 97-106.

Inderjit, Wardle, D.A., Karban, R., Callaway, R.M., 2011. The ecosystem and evolutionary contexts of allelopathy. Trends Ecol. Evol. 26, 655-662.

Kulmatiski, A., Beard, K.H., Stevens, J., Cobbold, S.M., 2008. Plant-soil feedbacks: a meta-analytical review. Ecol. Lett. 11, 980-992.

Leishman, M.R., Thomson, V.P., 2005. Experimental evidence for the effects of additional water, nutrients and physical disturbance on invasive plants in low fertility Hawkesbury Sandstone soils, Sydney, Australia. J. Ecol. 93, 38-49.

Lenz, T.I., Facelli, J.M., 2005. The role of seed limitation and resource availability in the recruitment of native perennial grasses and exotics in a South Australian grassland. Aust. Ecol. 30, 684-694.

Lozon, J.D., MacIsaac, H.J., 1997. Biological invasions: are they dependent on disturbance? Environ. Rev. 5, 131-144.

MacDougall, A.S., Turkington, R., 2005. Are invasive species the drivers or passengers of change in degraded ecosystems? Ecology 86, 42-55.

Maron, J.L., Marler, M., 2008. Effects of native species diversity and resource additions on invader impact. Am. Nat. 172, S18-S33.

Michalet, R., Xiao, S., Touzard, B., Smith, D.S., Cavieres, L.A., Callaway, R.M., Whitham, T.G., 2011. Phenotypic variation in nurse traits and community feedbacks define an alpine community. Ecol. Lett. 14, 433-443. 
Montesinos, D., Santiago, G., Callaway, R.M., 2012. Neo-allopatry and rapid reproductive isolation. Am. Nat. 180, 529-533.

Munshaw, M.G., Lortie, C.J., 2010. Back to the basics: using density series to test regulation versus limitation for invasive plants. Plant Ecol. 211, 1-5.

Pearson, D.E., Callaway, R.M., Maron, J.L., 2011. Biotic resistance via granivory: establishment by invasive, naturalized, and native asters reflects generalist preference. Ecology 92, 1748-1757.

Pitcairn, M.J., DiTomaso, J.M., 2000. Range-land and uncultivated areas: integrating biological control agents and herbicides for starthistle control. In: Hoddle, M.S. (Ed.), California Conference on Biological Control. UC Div Agri Nat Resources, Oakland.

Qin, B., Lau, J., Kopshever, J., Callaway, R., McGray, H., Perry, L.G., Weir, T.L., Paschke, M.W., Hierro, J.L., Yoder, J., Vivanco, J.M., Strauss, S., 2007. No evidence for root-mediated allelopathy in Centaurea solstitialis, a species in a commonly allelopathic genus. Biol. Invasions 9, 897-907.

Schaffner, U., Ridenour, W.M., Wolf, V.C., Bassett, T., Muller, C., Muller-Scharer, H., Sutherland, S., Lortie, C.J., Callaway, R.M., 2011. Plant invasions, generalist herbivores, and novel defense weapons. Ecology 92, 829-835.

Sun, M., Ritland, K., 1998. Mating system of yellow starthistle (Centaurea solstitialis), a successful colonizer in North America. Heredity 80 225-232.

Svensson, J.R., Nylund, G.M., Cervin, G., Toth, G.B., Pavia, H., 2013. Novel chemical weapon of an exotic macroalga inhibits recruitment of native competitors in the invaded range. J. Ecol. 101, 140-148.

Swope, S.M., Parker, I.M., 2010a. Trait-mediated interactions and lifetime fitness of the invasive plant Centaurea solstitialis. Ecology 91, 2284-2293.

Swope, S.M., Parker, I.M., 2010b. Widespread seed limitation affects plant density but not population trajectory in the invasive plant Centaurea solstitialis. Oecologia 164, 117-128.
Travis, J.M.J., Brooker, R.W., Dytham, C., 2005. The interplay of positive and negative species interactions across an environmental gradient: insights from an individual-based simulation model. Biol. Lett. 1, 5-8.

Travis, J.M.J., Brooker, R.W., Clark, E.J., Dytham, C., 2006. The distribution of positive and negative species interactions across environmental gradients on a dual-lattice model. J. Theor. Biol. 241, 896-902.

Turner, C.E., Fornasari, L., 1992. Biological control of yellow starthistle, Centaurea solstitialis, in North America. In: Delfosse, E.S., Scott, R.R. (Eds.), Proceedings of the 8th International Symposium on Biological Control of Weeds. Lincoln University, Canterbury, New Zealand, pp. 405-410.

Uygur, S., Smith, L., Uygur, F.N., Cristofaro, M., Balciunas, J., 2004. Population densities of yellow starthistle (Centaurea solstitialis) in Turkey. Weed Sci. 52, $746-753$.

Von Holle, B., Simberloff, D., 2005. Ecological resistance to biological invasion overwhelmed by propagule pressure. Ecology 86, 3212-3218.

Wallace, J.M., Wilson, L.M., Launchbaugh, K.L., 2008. The effect of targeted grazing and biological control on yellow starthistle (Centaurea solstitialis) in canyon grasslands of Idaho. Rangeland Ecol. Manag. 61, 314-320.

Wilensky, U., 1999. NetLogo. Center for Connected Learning and Computer-Based Modeling, Northwestern University, Evanston, IL, http://ccl.northwestern.edu/netlogo/.

Xiao, S., Michalet, R., Wang, G., Chen, S.Y., 2009. The interplay between species' positive and negative interactions shapes the community biomass-species richness relationship. Oikos 118, 1343-1348.

Xiao, S., Zobel, M., Szava-Kovats, R., Partel, M., 2010. The effects of species pool, dispersal and competition on the diversity-productivity relationship. Glob. Ecol. Biogeogr. 19, 343-351.

Yamamura, N., Higashi, M., Behera, N., Wakano, J.Y., 2004. Evolution of mutualism through spatial effects. J. Theor. Biol. 226, 421-428. 

Model description in the ODD protocol

The model description follows the ODD (overview, design concepts and details) protocol for describing individual- and agent-based models (Jovani and Grimm 2008; Grimm et al. 2010). The model is implemented in NetLogo (Wilensky, 1999. http://ccl.northwestern.edu/netlogo/) and available in the electronic supplementary material (basic model).

1. Purpose. The purpose of the model is to explore how integrating empirical results from experiments might help to elucidate the relative importance of seed origin (biogeographic differences) in competitive outcomes and disturbance in exotic plant invasion.

2. State variables and scales. We used an RII matrix to build an individual-based spatially-explicit dual-lattice model (Travis et al. 2005, 2006, Michalet et al. 2011) with $C$. solstitialis and all native species occupying one two-dimensional lattice $(100 \times 100$ cells $)$ for California and Spain, respectively. $r_{C}$ was the reproductive rate of $C$. solstitialis plant and $r_{N}$ was the reproductive rate of the native species. $S_{i}$ was the survival rate of the species. To account for the impact of disturbance, we defined $d$ as the intensity of disturbance in both the native and non-native ranges, ranging from 0 to 1 . We used a "wraparound" (torus) approach to avoid edge effects (Yamamura et al. 2004). All simulations were run for 10,000 time 
steps in order to allow the system to reach a steady state. However, note that all simulations reached stable proportional of species before 100 generations. Centaurea solstitialis was introduced to California roughly 200 years ago, thus even assuming a time lag from the first introduction until high densities were reached our simulations generally correspond with the timeframe of C. solstitialis invasion.

3. Process overview and scheduling. Each individual of each $C$. solstitialis and each native species occupied one cell in the lattice. The propagules were only allowed to establish in empty cells and the propagule arriving first occupied the cell. When reproduction occurred (annually), individuals produced propagules that were identical to their parents. All propagules of $C$. solstitialis and native species were dispersed sequentially to one of the patches that were randomly selected within the lattice. We used asynchronous updating in the model that worked in the following way. First a single individual of species was selected at random. Second, we determined whether the individual survived at a certain survival rate $S_{i}$. If the individual survived it reproduced and dispersed propagules. Each time step was made up of $N$ of such updates, where $N$ referred to the number of all individuals within the community.

4. Design concepts. We assumed that both intra- and inter-specific competition decrease the survival rate of the species, and that this negative effect increases linearly with the increase of the RII value. We also assumed that the impact of disturbance also decreased the survival rate of species and that this impact 
increased linearly with the increase of the $d$ value. Individuals competed only with other individuals within a neighborhood, and the neighborhood was defined as the Moore neighborhood in our model, including eight immediate neighbors of a given cell: north, northeast, east, southeast, south, southwest, west and northwest (Ifti et al. 2004). All measurements were determined as the mean values of 100 independent replicate runs for each time step.

5. Initialization. Since the initial population sizes of invaders are likely to be relatively small at the beginning of invasions, all simulations were initiated with only 100 individuals of California C. solstitialis. Initial conditions started with saturated communities of native species with each having the same number of individuals. All individuals of species were randomly dispersed across the lattice.

6. Input. The total number of these propagules equalled the reproductive rate $r_{C}$ of the $C$. solstitialis plant and the reproductive rate $r_{N}$ of the native species. $r_{C}$ was 5.598 in California and 3.045 in Spain, and $r_{N}$ was the same for all native species populations, which equaled 4.321. As described above, $c$ equals 0.403 for Californian C. solstitialis, and 1 for Spanish C. solstitialis, and 1 for all native species both from North America and Europe.

7. Submodels. The survival rate of species $i$ experiencing disturbance was:

$$
S_{i}=S_{\max }(1-c * d)-\sum_{j=1}^{n}\left(R I I_{j \text { on i }} / 8\right)
$$

where $S_{\max }$ was the maximum survival rate of the species without competition, and we assumed that it was the same for all species, with a value equal to 0.8 . However, we conducted a sensitivity analysis with $S_{\max }$ values equalling to 0.4 , 
0.6 and 1.0, to confirm the robustness of our models. $R I I_{j \text { on } \mathrm{i}}$ indicates the competitive RII values of neighboring species $j$ on species $i . n$ is the total number of neighboring plants of one individual of species $i .1$. $d$ was set to 0 (no disturbance), 0.1 (low disturbance), 0.4 (moderate disturbance) and 0.7 (high disturbance).

\section{References}

Grimm V., Berger U., DeAngelis D.L., Polhill J.G., Giske, J. \& Railsback S.F. 2010. The ODD protocol: a review and first update. Ecological modelling, 221: 2760-2768. Ifti M., Killingback T. \& Doebeli M. 2004. Effects of neighbourhood size and connectivity on the spatial Continuous Prisoner's Dilemma. Journal of Theoretical Biology 231: 97-106.

Jovani R. \& Grimm V. 2008. Breeding synchrony in colonial birds: from local stress to global harmony. Proceedings of the Royal Society of London B: Biological Sciences 275: 1557-1564.

Michalet R., Xiao S., Touzard B., Smith D.S., Cavieres L.A., Callaway R.M. \& Whitham T.G. 2011. Phenotypic variation in nurse traits and community feedbacks define an alpine community. Ecology Letters 14: 433-443.

Travis J.M.J., Brooker R.W. \& Dytham C. 2005. The interplay of positive and negative species interactions across an environmental gradient: insights from an individual-based simulation model. Biology Letters - UK 1: 5-8. 
87 positive and negative species interactions across environmental gradients on a

88 dual-lattice model. Journal of Theoretical Biology 241: 896-902.

89 Yamamura N., Higashi M., Behera N. \& Wakano J.Y. 2004. Evolution of mutualism

90 through spatial effects. Journal of Theoretical Biology 226: 421-428. 
globals [ $r n$ is Su rinv trinv1 trinv2 trinv3 trn1 trn2 trn3]

patches-own [s]

to setup

clear-all

crt (totaltime +1 )

if Invader = "California_C_solstitialis" and Place = "America"

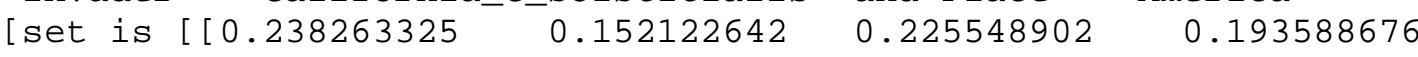

$\odot .084776013]$

$\begin{array}{lllll}0.07119255] & {[0.106690778} & 0.243571763 & -0.028222555 & 0.145407112 \\ 0.347694633] & {[0.387230827} & 0.491867639 & 0.142315504 & 0.321400285 \\ 0.343379167] & {[0.378378378} & 0.420940171 & 0.247928994 & 0.301404056 \\ {[0.490864799} & 0.460735859 & 0.150572831 & 0.250862198\end{array}$

$\odot .21540559]$

if Reproductive_difference = "With"

[set rinv 5.598]

if Reproductive_difference = "Without"

[set rinv 4.32134]

ask patches

[set $s$ 5]

ask n-of 100 patches

$\left[\begin{array}{lll}\text { set } & 0\end{array}\right]$

ask turtles with [who $<5$ and who $>0$ ]

[let temp who

ask n-of ((count patches - 100) / 4) patches with [s = 5]

[set s temp]]]

if Invader = "Spanish_C_solstitialis" and Place = "America"
[set is [ [0.297709924
0.058504875
$\odot .201565558$
$\odot .175240828$
$0.075202885]$
$\odot .07119255]$
$[\odot .092244898$
$\odot .243571763-\odot .028222555$
$\odot .145407112$
$\odot .347694633]$
$[0.451980467$
$\odot .491867639$
$\odot .142315504$
$\odot .321400285$
๑. 343379167]
$[0.44414463$
$\odot .420940171$
$\odot .247928994$
$\odot .301404056$
$[\odot .52739726 \quad 0.460735859$
0.150572831
$\odot .250862198$

$\odot .21540559]$

if Reproductive_difference = "With"

[set rinv 3.04468]

if Reproductive_difference = "Without"

[set rinv 4.32134]

ask patches

[set $s$ 5]

ask n-of 100 patches

$\left[\begin{array}{lll}\text { set } & s & 0\end{array}\right]$

ask turtles with [who $<5$ and who $>0$ ]

[let temp who

ask $n$-of ((count patches - 100) / 4) patches with [s = 5] 


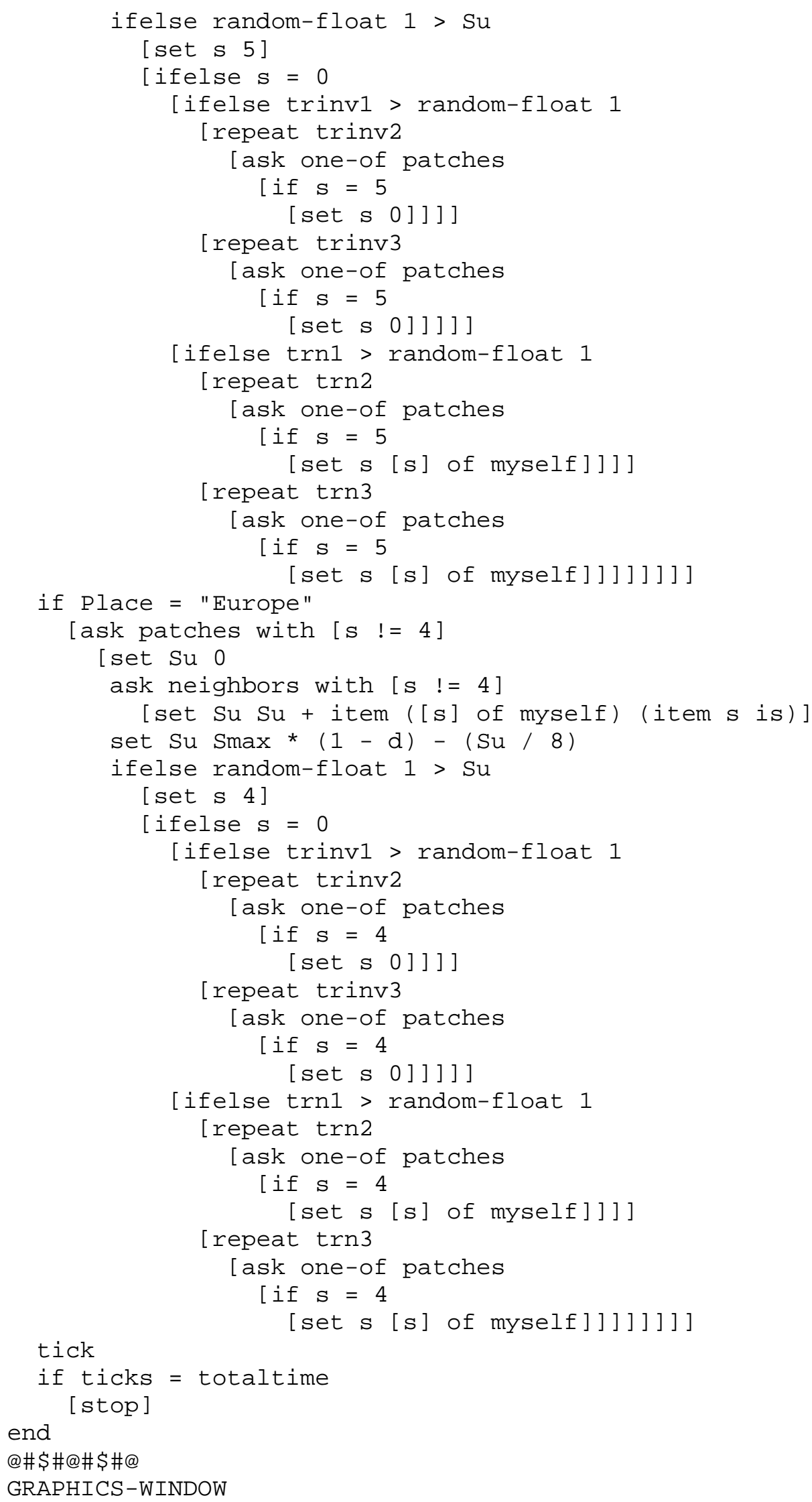


$-1$

$-1$

10.3

1

10

1

1

1

○

1

1

1

$\odot$

99

$\odot$

99

1

1

1

ticks

30.0

BUTTON

10

10

94

44

NIL

setup

NIL

1

$\mathrm{T}$

OBSERVER

NIL

NIL

NIL

NIL

1

BUTTON

108

10

172

44

NIL

go

$\mathrm{T}$

1

$T$

OBSERVER 


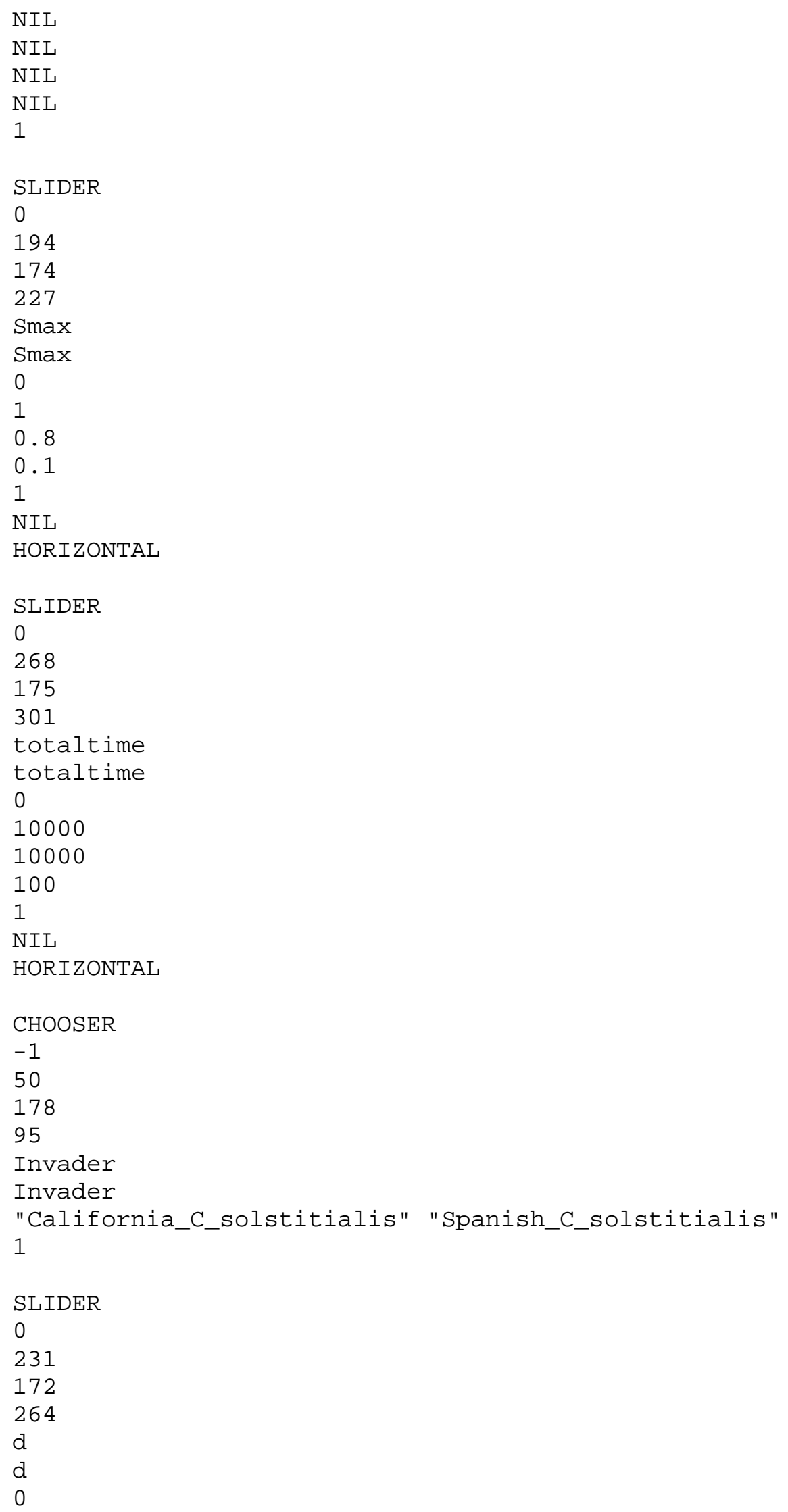




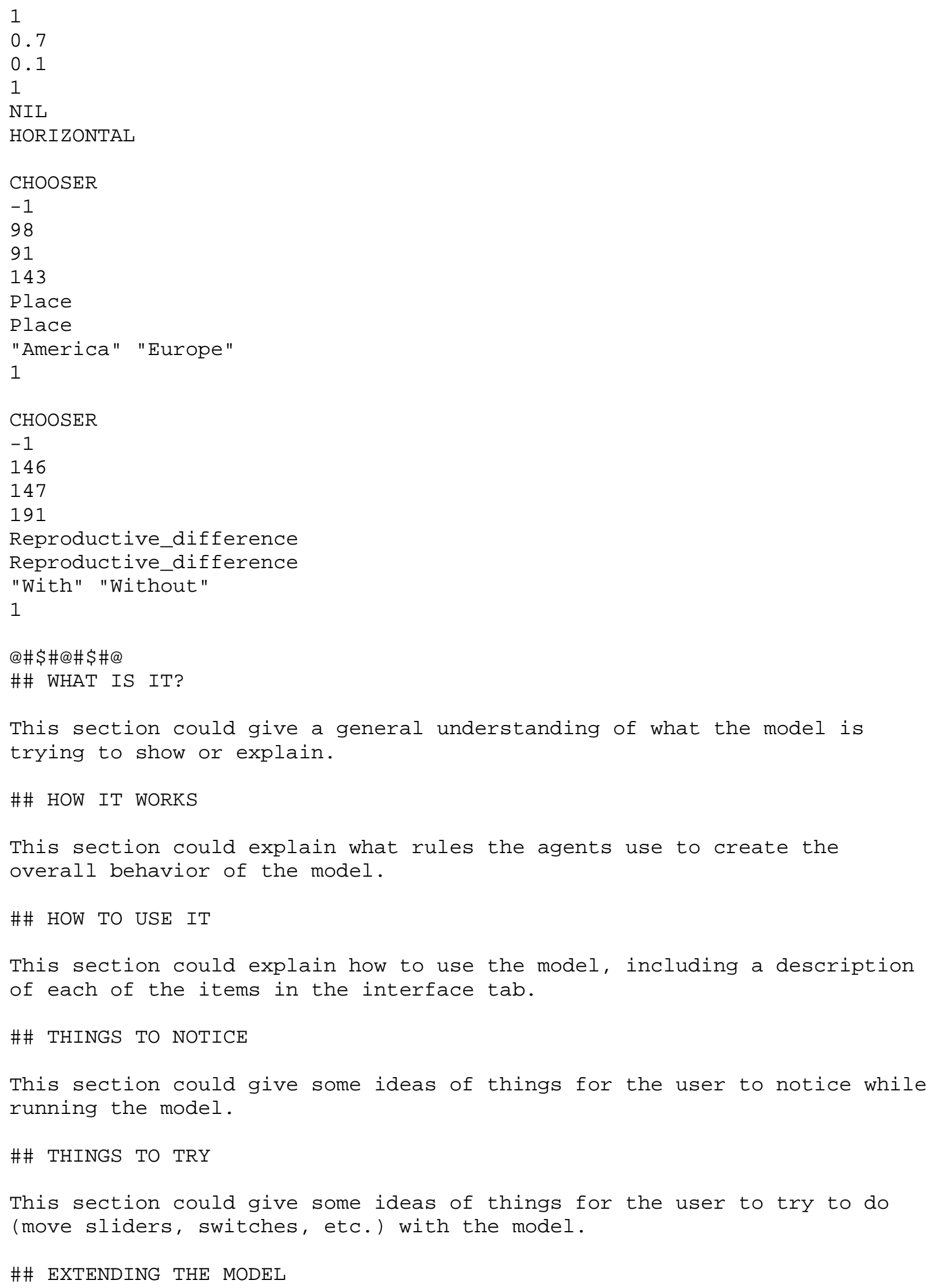


This section could give some ideas of things to add or change in the procedures tab to make the model more complicated, detailed, accurate, etc.

\#\# NETLOGO FEATURES

This section could point out any especially interesting or unusual features of NetLogo that the model makes use of, particularly in the Procedures tab. It might also point out places where workarounds were needed because of missing features.

\#\# RELATED MODELS

This section could give the names of models in the NetLogo Models Library or elsewhere which are of related interest.

\#\# CREDITS AND REFERENCES

This section could contain a reference to the model's URL on the web if it has one, as well as any other necessary credits or references. @\#\$\#@\#\$\#@

default

true

$\odot$

Polygon -7500403 true true 150540250150205260250

airplane

true

$\odot$

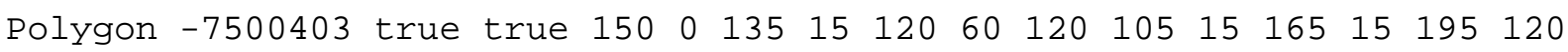

$\begin{array}{llllllllllllllllll}180 & 135 & 240 & 105 & 270 & 120 & 285 & 150 & 270 & 180 & 285 & 210 & 270 & 165 & 240 & 180 & 180 & 285\end{array}$

$\begin{array}{lllllllll}195 & 285 & 165 & 180 & 105 & 180 & 60 & 165 & 15\end{array}$

arrow

true

$\odot$

Polygon -7500403 true true 150000150105150105293195293195150 300150

box

false

$\odot$

Polygon - 7500403 true true 15028528522528575150135

Polygon -7500403 true true 15013515751501528575

Polygon -7500403 true true $\begin{array}{llllllll}75 & 15 & 225 & 150 & 285 & 150 & 135\end{array}$

Line - 16777216 false 150285150135

Line -16777216 false 1501351575

Line -16777216 false 15013528575

bug

true

$\odot$

Circle -7500403 true true 96182108 


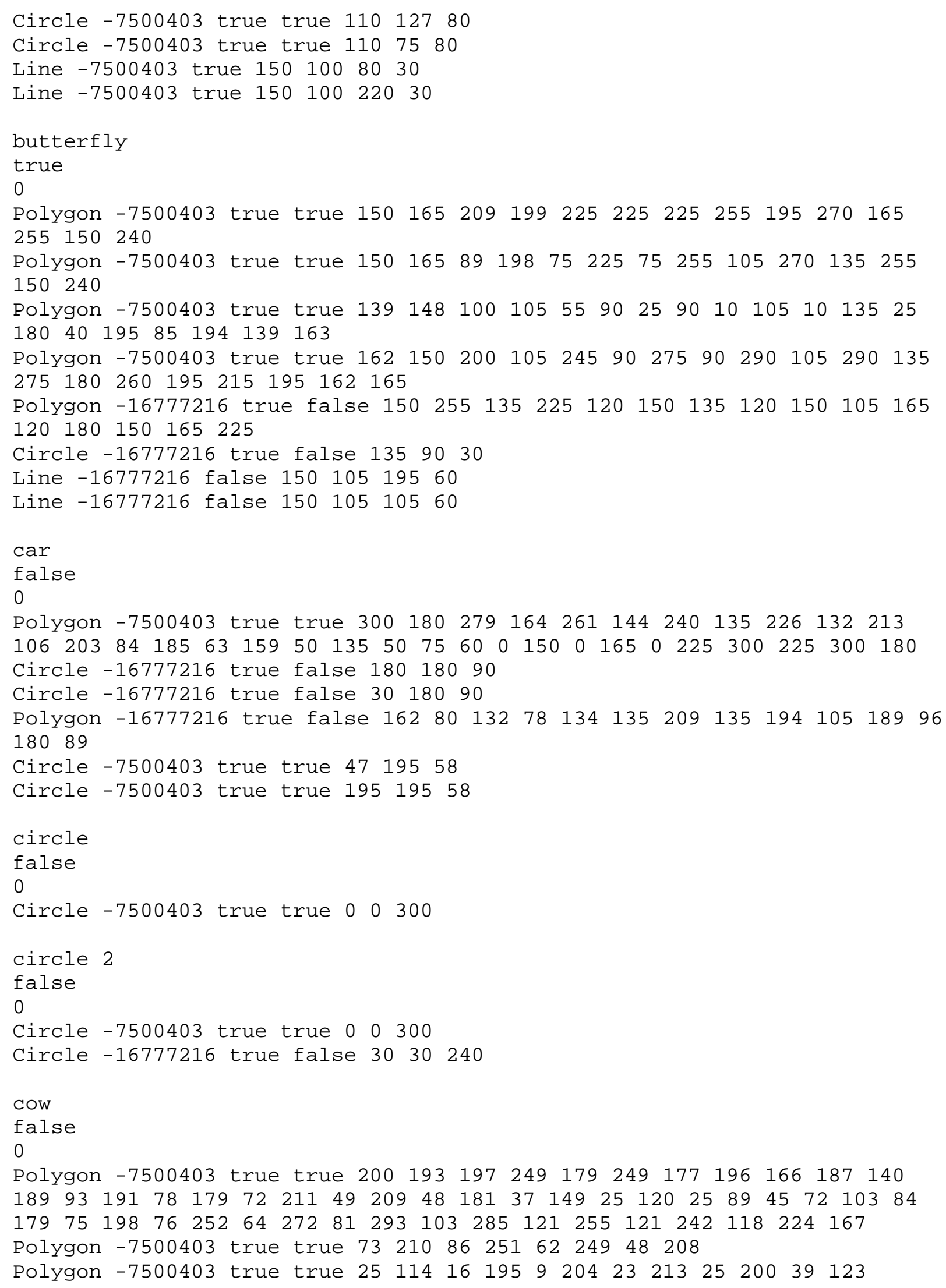




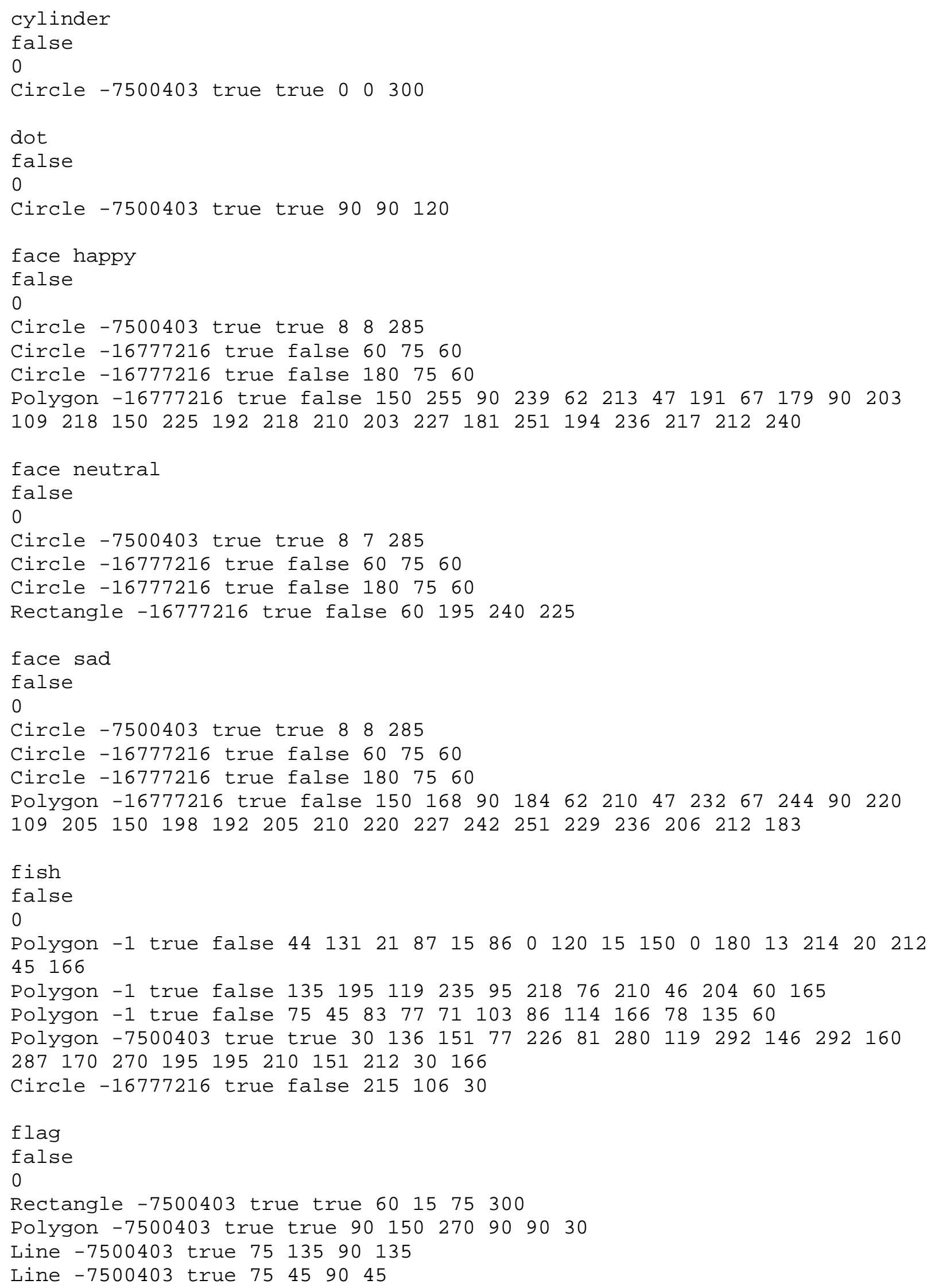




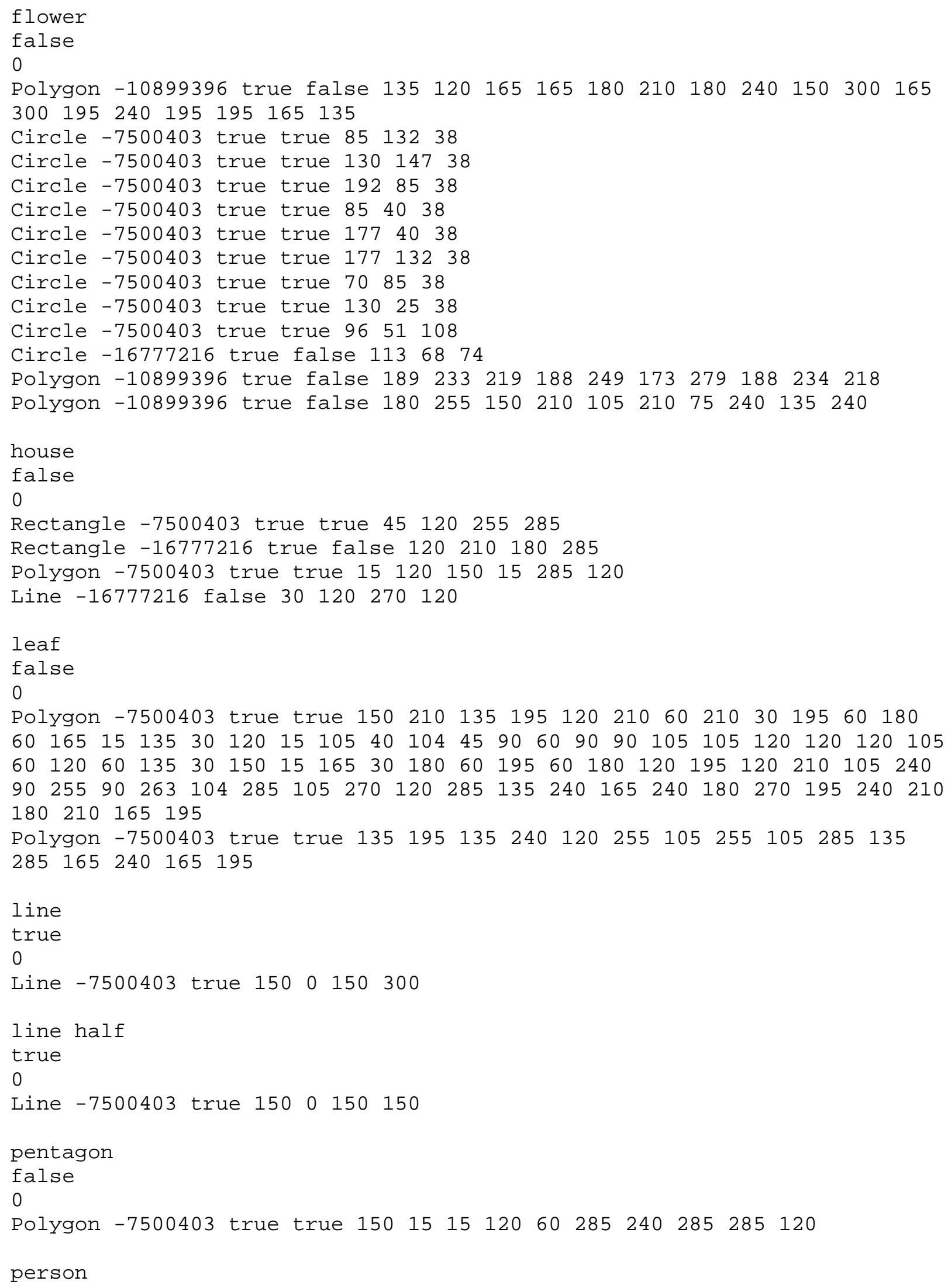




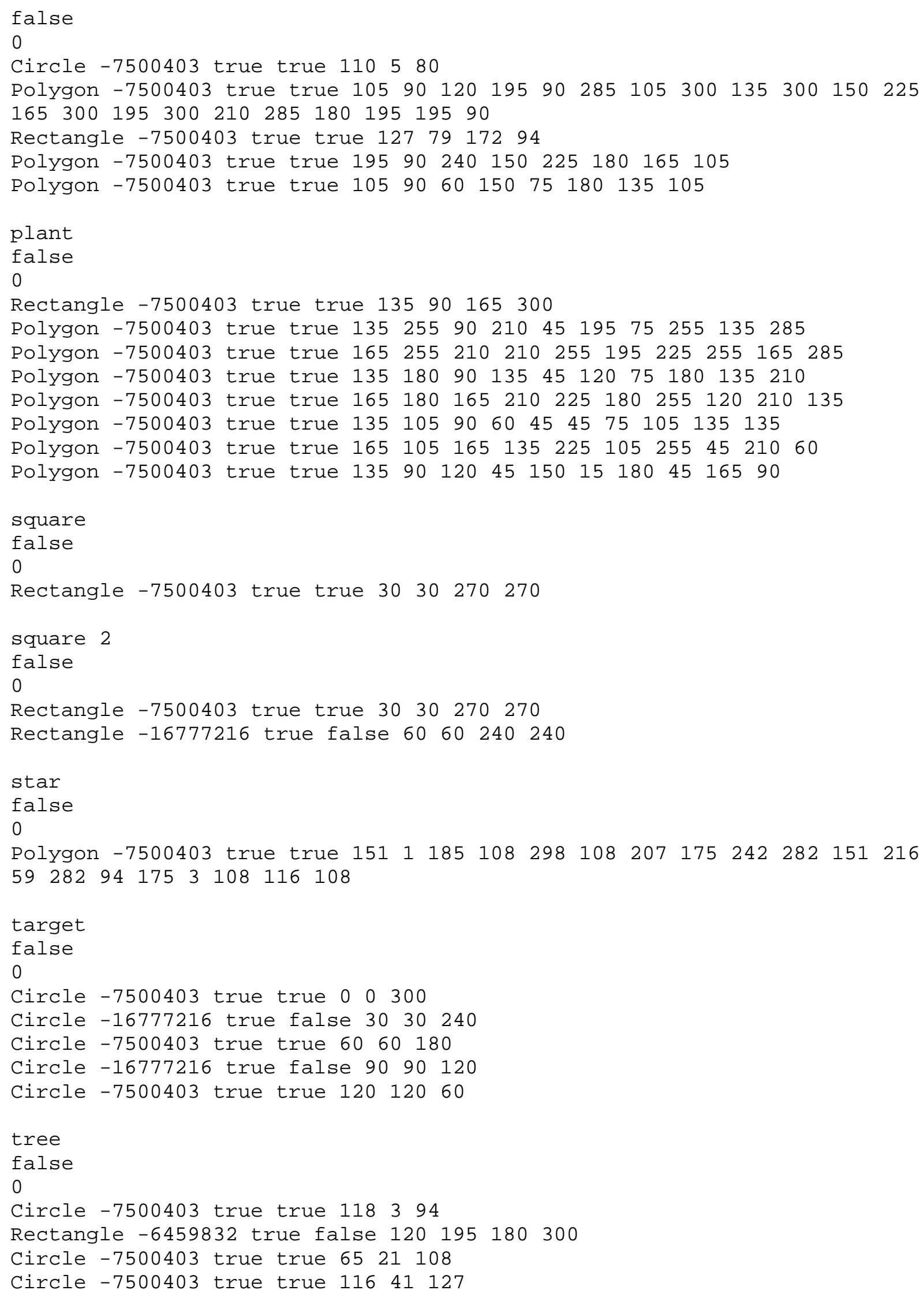




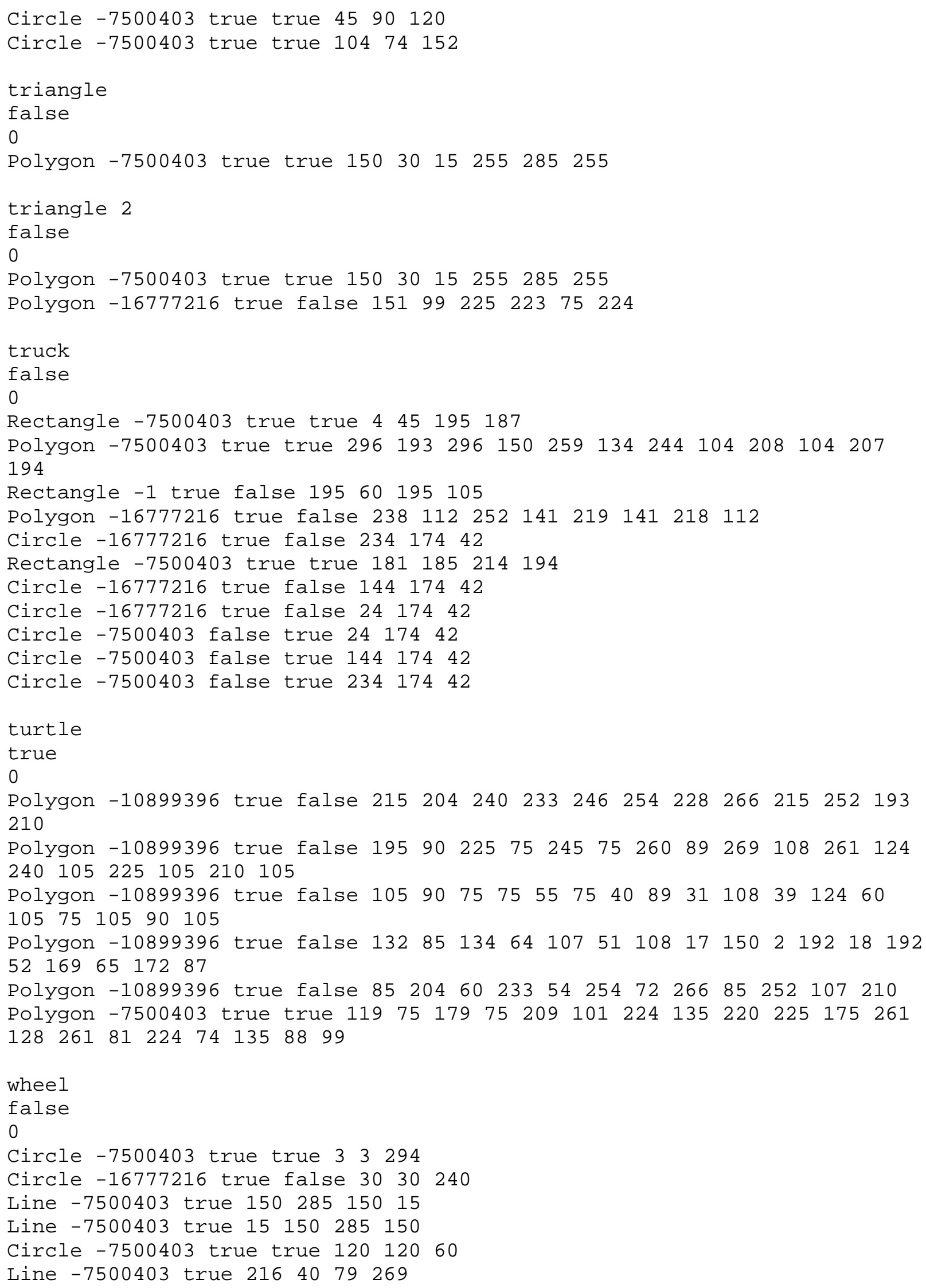




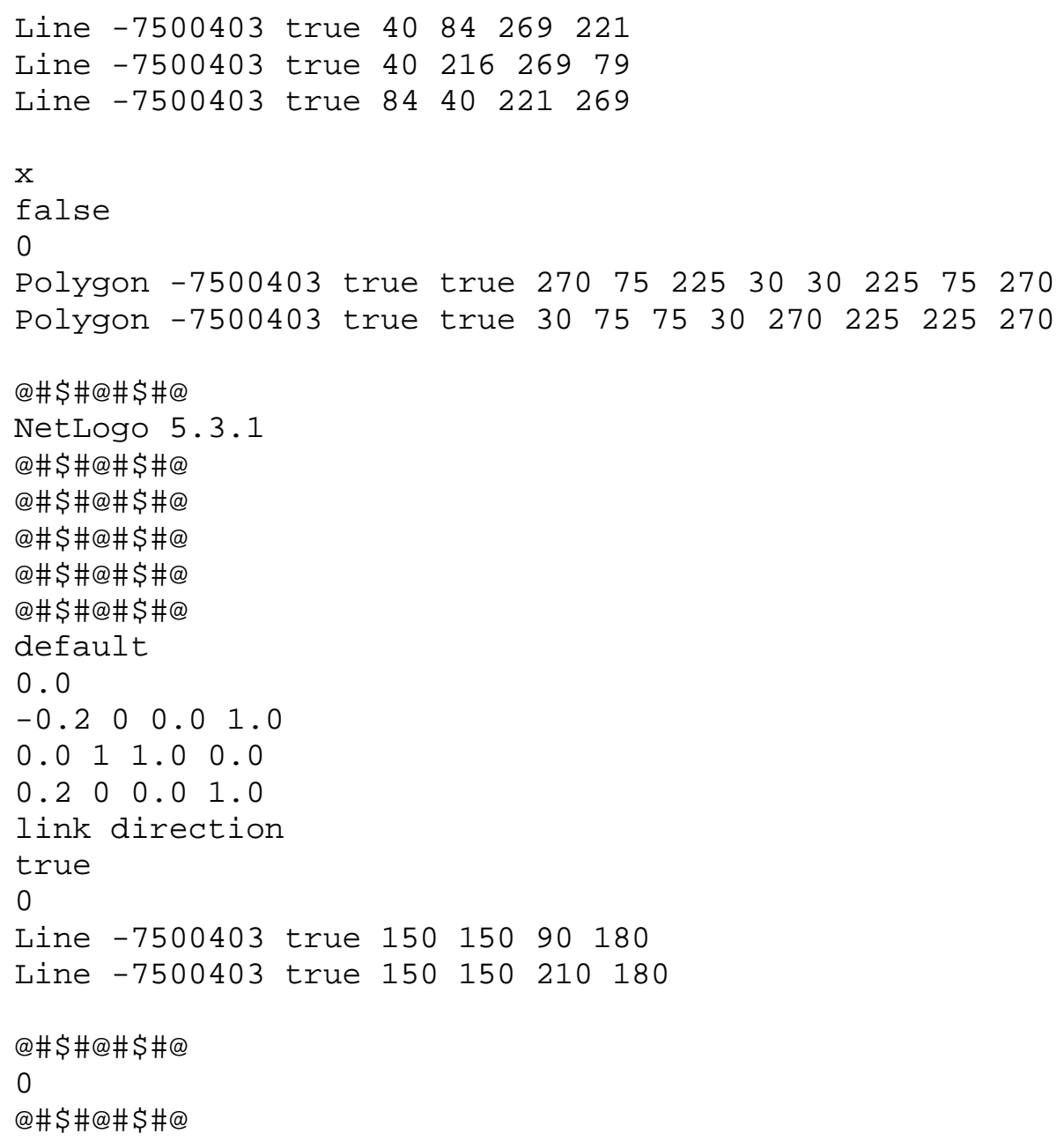

